\title{
PROBLEMS AND SOLUTIONS OF NEPALESE HUMAN TRAFFICKING IN INDIA
}

\author{
Kumar, $\operatorname{Aman}^{7}$
}

\begin{abstract}
Human trafficking arise from Labor Migration, Poverty, Exclusion, Attractions of Cities, Open Boarder, Active Trafficker, Bad Governance and solutions for the problems are Inland Job Opportunity, Poverty Alleviation Programs, Inclusion and Participation, Rural Education, Secured Boarder, Active Social Worker and Good Governance are urgently needed in Nepal. To identify the problem and solutions of human trafficking from Nepal the study has been conducted. In-depth interview method had been applied and had interviewed with security personnel of the Sunauli boarder of both countries. Prevention, Care, Monitoring and Evaluation from both countries are also necessary. Entire issues of problem and solutions of human trafficking in between India and Nepal are virgin area of research.
\end{abstract}

Keywords: Human Trafficking, Problem, Solutions

\section{Introduction}

Nepal and India are open boarder neighboring countries in South Asia. Nepal is tiny land linked developing country and famous with Lumbini- Birth Place of Lord Buddha, Pashupatinath- Land of Lord Shiva, Sagarmatha - Highest peak in the world, the Mt. Everest, and Janakpur - birth place of renowned oriental scholar king Janak and goddess Sita. India is the world's $4^{\text {th }}$ largest democracy, a nuclear powered nation, and international hub of eastern philosophy, knowledge, and civilization. India is the largest country in south Asia. Both the countries have long historical and cultural tie up with numbers of similarities. As close neighbors, India and Nepal share unique ties of friendship and cooperation characterized by an open border and deep-rooted people-topeople contacts of kinship and culture. There has been a long tradition of free movement of people across the border. Nepal shares a border of over $1850 \mathrm{~km}$ with five Indian states - Sikkim, West Bengal, Bihar, Uttar Pradesh and Uttarakhand. Due to the autocratic rules of Rana, Saha, Panchayat and ten years long Maoists people's war, Nepal is still crawling through poverty and bad governance. Being an open boarder and poverty labor migration is easy and human trafficking is being a dangerous misconduct. Trafficking, an organized crime, is becoming more vulnerable problem in developing world, especially in those countries which are undergoing socio-economic transformation. Mass human displacement from the areas which have been experiencing harshness $7 \quad$ Mr. Kumar is Research Scholar at Centre for the Study of Nepal FSS Banaras Hindu University can be contacted at aman0907@yahoo.com 
Research Nepal Journal of Development Studies (Year $2^{\text {nd }}$ Issue $1^{\text {st }}, 2019$ May)

in climatic conditions, or those which have witnessed long- unbearable never ending wars and internal insurgencies, have lead increase in trafficking (Bhardwaj, 2010). Human trafficking from Nepal to India is in similar trend.

The trafficking of girls from Nepal into India for forced prostitution is perhaps one of the busiest slave trafficking routes anywhere in the world, with estimated 5,000-10,000 Nepali women and girls trafficked to India each year (Koirala, Banskota, \& Khadka, 2004). An estimated 100,000200,000 Nepali trafficked persons are in India. Nepali girls are especially desirable as prostitutes in India because they are considered more attractive due to their lighter skin color, and because Nepali virgins are believed to be able to cure AIDS. Victims are also trafficked for labor in circuses, agriculture, and other manufacturing sectors (Koirala, Banskota, \& Khadka, 2004). The 1850 kilometers of open, porous border between Nepal and India make trafficking simple and difficult to catch. In addition, there is no immigration control for Nepalese migrating to India or Indians coming in Nepal under the 1950 Peace and Friendship Treaty between India and Nepal. Various studies reveal that trafficking from Nepal in India, or even within Nepal and India, is really a severe problem to both states and societies. Forced involvement of innocent women and girls in India, especially cruelly forced teenagers, is havoc to the cultured society (Bhardwaj, 2010). India is an intermittent market for the traffickers however it is equally true that there is a lot of scope to this business in India itself. In addition to being a destination, India is also a transit country for Nepalese and Bangladeshi women trafficked to Pakistan, Western Asia, and the Middle East and for women trafficked from the Russian Federation to Thailand (Koirala, Banskota, \& Khadka, 2004). Therefore, to identify the problems and its solution the study has been conducted.

\section{Review}

Trafficking of Nepalese women and girls to Indian brothels was established in 1960. Even before that during the Rana rule in Nepal women required a special authorization to go to India. About 50 percent of Nepal's female sex workers have previously worked in Mumbai and more than 200,000 Nepalese girls are involved in the Indian sex trade (Joshi, 2010). At the local level, trafficking involves deep-rooted processes of gender discrimination, lack of female education, ignorance and naiveté of rural folk, poverty and lack of economic opportunities in rural areas, with consequent marginalization of particular social groups.

These processes are influenced by macro-level economic and social changes that are altering marketing traditions and labor requirements (Evans \& Bhattarai, 2000). These factors, combined with modern marketing techniques, are also changing (and perhaps unrealistically raising) people's fundamental expectations of life and what 'basic needs' are. While some of these 
Kumar, Aman

proposed causes can be said to increase vulnerability specifically to trafficking (e.g., women's lack of empowerment or lack of information about what may happen if they migrate), the rest are part of changes happening globally that are leading both to the increased feminization of poverty and to increased female migration. Hence, they are factors that lead to the desire or need to migrate. Again, it is perhaps misleading to single these factors out as being fundamental causes of trafficking per se. Rather, these factors underlie the phenomenon of increased migration, with some people being trafficked as a result.

\section{Objectives and Methodology}

To find out the problems and solutions of Nepalese Human Trafficking in India the study has been conducted. Methodologically the study is based on secondary data and literature review. Primary data were collected from security personnel of both countries at Sunauli Boarder from in depth interview. The discussions about the problems and solutions are presented according to the response of security staffs working in boarder area.

\section{Problems}

\section{a. Labor Migration}

Most the cases are related in the search of job and dream of happy life in city. It has been found that many Nepalese have been internally migrating in the course of the long-running internal conflict and improper development. Most of the reports indicate that internal displacement is caused by the direct or indirect action of clashes between groups like between Madhesis and peoples of high hill. This migration typically occurs from rural areas to urban centers like near to capital city Kahmandu because of the availability of good recourses and good life slandered. Sometime criminal and other big contractors recruit poor peoples in different industries by luring of giving false promises and by this way they get victim trafficking or forced labors. The presence of such gangs in the Nepal contributes to the human trafficking and forced labor in Nepal. In this poor Nepalese due to lack of financial support, unavailability of work, attraction towards big metropolitan cities forced them to do unsafe migration. In certain districts of Nepal, the out migration of men and women of prime productive and reproductive age is particularly high. And due to lack of knowledge of safe migration these Nepalese get victim of trafficking. Due to lack of knowledge of safe migration they become the victim of trafficking.

\section{b. Poverty}

Women and children are trafficked into becoming child labor and maid servant in India. Even 
Research Nepal Journal of Development Studies (Year $2^{\text {nd }}$ Issue $1^{\text {st }}, 2019$ May)

women and small children are also trafficked for sex industry in India. From India these Nepalese are also being trafficked to other south Asian Countries and Gulf Countries from India. These women and children are also trafficked for forced labor, sexual slavery, forced to sell drugs and beggaring in India. It is only due to the poverty of Nepal.

\section{Exclusion}

Nepal is particularly afflicted by the scourge of human trafficking. All the elements of modernday slavery and human exploitation are present in Nepal that is struggling to overcome decades of internal conflict, social discrimination and poverty. Nepalese officials, estimates that more than 70,000 Nepalese are trafficked from Nepal each year.

\section{d. Attractions of Cities}

The big cities of India are the center for attraction of poor youths of Nepal. Nepal has the culture of Lahure- people from Nepal used to go to join in British Indian Army in Lahore. The culture is still prevailing in different shapes we can call it labor migration now. Nepal must be able to teach the pros and cons of hifi urban life and foreign job market.

\section{e. Open Boarder}

Boarder is open. Anyone can enter and exit any time with any kind of purpose. That freedom is the problem of trafficking. Broader should be people friendly and systemized.

\section{f. Active Traffickers}

Indian policy on brothel should be revised. The prostitutes must have Citizenship Card, Regular Health checkup status, Tax record and many more so that traffickers do not get chance to admit innocent girls.

\section{g. Bad Governance}

The biggest problem of south Asia is Bad Governance. India is also seriously suffering from grass root level. Indian local governments must be responsible for to stop like such criminal activities. Nepal is till now in political crisis. Let's hope new democratic government must be able to tackle the problems.

\section{Solutions}

\section{a. Inland Job opportunity}


Kumar, Aman

Nepal must be able to create inland job opportunities for vulnerable women and good school system to children. Nepal must be able to manage the problem of labor migration in India. $90 \%$ around Nepalese women migrant laborers to India are in the trap of traffickers. The data shows the situation is intensively dangerous on social harmony.

\section{b. Poverty Alleviation Programs}

Nepal is extensively working on poverty alleviation program although it has not taken proper shape. Nepal has to increase the intensity. Indian government must assist Nepal in financial arrangements. Poverty Alleviation Fund of Nepal is working on this issue.

\section{c. Inclusion and Participation}

From the new constitution of Nepal 2015 Nepal has accepted the values and norms of inclusive and participative governance. It may take some time to achieve the goal so India has to play a scientific role to solve the problem. There is a serious allegation to India that in Nepal India has shown only interest in Tarai and Madhes but the people want India has to play effective helpful neighboring role on the development of Hills and Mountains as well.

\section{d. Rural Education}

Gandhian Model of Rural Development is fore most useful in Nepal. There are many more villages in Nepal that access of central government is considerably low. The Gandhian Model of Swaraj will be recommended for poor hilly villages of Nepal. Gandhian Education system like Nai Talim etc. are important. India must be able to indulge on Gandhian philosophy in Nepal.

\section{e. Secured Boarder}

Controlling of boarder does not mean the minimization of friendship. This is very big misconception in boarder sides. There must be a people friendly mechanism in boarder. At least there must have recording system of entrance and exit of the people of both countries. Respecting friendship Nepal and India must control the boarder for security purposes.

\section{f. Active Social Worker}

NGOs of Nepal and India should be trained as social welfare organization rather than fund consumption partner of INGOs or governments. Trafficking is serious social problem arisen from economic condition. It is the issue of humanitarian vibe. Entire social workers must be active and motivated against the trafficking. Their active role and empowerment plays a significant role to 
Research Nepal Journal of Development Studies (Year $2^{\text {nd }}$ Issue $1^{\text {st }}, 2019$ May)

mitigate the social crimes.

\section{g. Good Governance}

Good Governance system is worldwide accepted notion of governance system but Nepal is seriously suffering from corruption and policy corruption. Nepali citizen must be able to warn their democratically elected government. The corruption is also a serious problem in India. On the other hand, prostitution and sex tourism of India is the main cause of girls trafficking in India. Transparency and accountability in prostitution industry is urgently addressed.

\section{h. Prevention}

Most preventive interventions focus on: (i) improving women's opportunities in the village, (ii) keeping women in the village, and (iii) giving warnings about the potential dangers of trafficking and migration. These are valid activities but some IEC messages do not appear to be based on an informed understanding of local migration processes or on community needs/priorities. Given the reality that many women DO migrate or are trafficked, and that trafficking may occur in city workplaces as well as directly from rural areas, IEC materials need to be realistic and relevant and should include concrete relevant advice on how to migrate safely. There is also a need to establish support systems to enable safe migration and to help women once they are in the cities.

\section{i. Care and Support}

Current evidence suggests that care and support of rescued girls is a difficult and long-term process. NGOs engaged in this work require technical and financial support to develop systematic techniques for family assessment, counseling, intervention, and follow-up. Particular help is required to develop appropriate plans for girls who cannot return home and for those who are HIV positive. In particular, one current strategy of segregating HIV positive 'rescued' girls in a home in a remote district requires careful evaluation.

\section{j. Advocacy and networking}

There is a need for coordination and consistency in current advocacy work. An emphasis on promoting human rights and promoting safe migration may help to overcome some of the ideological differences (particularly with respect to sex work) that currently divide the field. NGOs working to prosecute anti-trafficking cases require more support. The cases they pursue should be documented and used in advocacy work with the judiciary.

\section{k. Monitoring and evaluation}


Kumar, Aman

Though a great deal of trafficking-related work is being done, most interventions have not been systematically documented or evaluated and on-going monitoring of programs is absent, ad hoc, or is insufficiently rigorous. Hence, at this stage, it is not possible to make informed judgments of an intervention's relative efficacy or sustainability. There is an urgent need to support NGOs to develop appropriate monitoring and evaluation mechanisms. Some formative research may first be required to develop appropriate process and impact indicators. Thorough documentation and sharing of experiences would greatly help to identify lessons learned and to build up a better understanding of which approaches work/do not work and why. This may be particularly useful for care and support strategies

\section{Suggested Remedies}

It is important for responsible parties to carry out public awareness raising the issue of trafficking and advocacy for survivors' rights. This will help to change negative attitude towards trafficking victims. The government should empower survivors by organizing skill oriented training and providing financial supports in order to enable them to acquire economic independence. This will have two benefits. On the one hand, survivors get opportunities and on the other, their information and knowledge would be more effective to conduct the programmes.

It is necessary to conduct gender sensitive programmes to enhance gender equality in the grass root levels to the policy level. This is because gender discrimination is one of the reasons that may signify traditional discriminatory practices in the society. Discriminatory laws should be abolished and new ones formulated. In addition, the existing rules and laws should be applied effectively.

It is important to ensure communities' participation in all anti-trafficking programmes, as this would ensure sustainability of the programmes.

There is a need for NGOs and donor agencies to develop conceptual clarity on trafficking

- in particular, on its relation to migration and sex work. Some interventions currently conflate these concepts leading to strategies that may (explicitly or implicitly) restrict women's freedom and right to mobility. This is particularly true in welfare-oriented interventions in which NGOs claim to know what is best for women/girls (including whether or not they should be allowed to migrate). Lack of conceptual clarity affects all phases of a project, including monitoring and evaluation. For example, some organizations equate keeping women in the village with success preventing trafficking. 
Research Nepal Journal of Development Studies (Year $2^{\text {nd }}$ Issue $1^{\text {st }}, 2019$ May)

There is a need for more research that informs intervention strategies and their subsequent monitoring and evaluation. Current information is largely anecdotal. Research should include:

- Analysis of the socio-economic context and process of female labor migration in Nepal and its linkages with trafficking. An understanding of this is fundamental to the development of appropriate intervention strategies.

- Documentation of known trafficking cases to develop a clearer picture of current trafficking methods, sites and processes, and also to develop a clearer picture of who is at risk and why and how to define vulnerability. This would assist the appropriate targeting of interventions.

\section{Conclusions}

Problems of human trafficking arise from Labor Migration, Poverty, Exclusion, Attractions of Cities, Open Boarder, Active Trafficker, Bad Governance and solutions for it are as follows: Inland Job opportunity, Poverty Alleviation Programs, Inclusion and Participation, Rural Education, Secured Boarder, Active Social Worker and Good Governance is urgently needed in Nepal. Prevention, Care monitoring and evaluation are also necessary. Boarder security strengthens the Nepal India Relations and reduces the human trafficking crime.

\section{References}

Bhardwaj, V. K. (2010). Women Trafficking from Nepal in India: Uncontrolled Problem and Helpless Victims. Jaipur- India: University of Rajasthan, South Asia Studies Centre -Post Doctoral fellow (ICSSR- India) .

Evans, C., \& Bhattarai, P. (2000). A Comparative Analysis of Anti-Trafficking Intervention Approaches in Nepal. Kathmandu and New Delhi: The Asia Foundation Kathmandu Population Council New Delhi.

Joshi, S. (2010). Human trafficking in Nepal: A rising concern for all. Kathmandu University Medical Journal (2010), Vol. 8, No. 1, Issue 29, , 3-4.

Koirala, A., Banskota, H., \& Khadka, B. (2004). Cross border interception - A strategy of prevention of trafficking women from Nepal. . Int Conf AIDS :15. 2004, Jul 11-16. Int Conf AIDS :15. 2004, Jul 11-16. 